\title{
CONTENT OF ALKYLRESORCINOLS IN CEREALS GROWN IN LATVIA DETERMINED BY HIGH PERFORMANCE LIQUID CHROMATOGRAPHY WITH UV
}

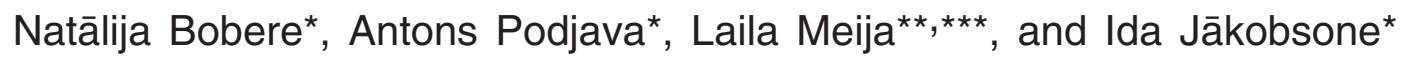 \\ * Faculty of Chemistry, University of Latvia, Kr. Valdemāra iela 48, Rīga LV-1013, LATVIA \\ ** Rīga Stradiṇš University, Dzirciema iela 16, Rīga LV-1007, LATVIA; natalia.bobere @icloud.com \\ *** Pauls Stradiṇš Clinical University Hospital, Pilsonu iela 13, LV-1002, Rīga, LATVIA
}

Communicated by Isaak Rashal

\begin{abstract}
Cereal alkylresorcinols (ARs) are a group of phenolic lipids mainly found in the outer parts of grains of rye and wheat. They have been suggested for use as selective biomarkers for intake of whole grain and bran products of these cereals. Consumption of whole grains and whole grain products has been associated with reduced risk of developing chronic diseases, such as cardiovascular disease, diabetes type 2, obesity and some types of cancer. In this article a sensitive and rapid method of High Performance Liquid Chromatography with UV detection for quantitative determination of ARs in the cereals grown in Latvia is described. Instrument detection limits (IDL) were determined for C17:0, C19:0 and C21:0 homologues (coefficient of variation < 3\%). According to the results of these studies, ARs were found in rye $(87.1-112.0 \mathrm{mg} / 100 \mathrm{~g})$, wheat $(24.0-40.2 \mathrm{mg} / 100 \mathrm{~g})$, triticale $(32.1-74.4 \mathrm{mg} / 100 \mathrm{~g})$, and in small amounts in barley (2.2-3.7 $\mathrm{mg} / 100 \mathrm{~g})$, but not in oats.
\end{abstract}

Key words: alkylresorcinols, HPLC-UV, whole grain cereal.

\section{INTRODUCTION}

Epidemiological studies have associated a diet rich in whole grain and cereal products with decreased risk of several chronic diseases, e.g. coronary heart disease (Liu et al., 1999), diabetes type 2 (Munter et al., 2007), obesity (Fung et al., 2001) and some cancers (Jacobs et al., 1998), although the mechanisms are poorly understood (Slavin, 2003). Also, there are concerns about the methodology used to determine dietary intake in epidemiological studies (Bingham et al., 2003). Studies are further complicated by the fact that consumers might have difficulty in identifying whole grain products (Lang and Jebb, 2003). Whole grain intake assessment also shares the common weaknesses, such as poor precision and bias, with assessment methods for other dietary constituents (Kaaks, 1997; Bingham et al., 2003). The use of a biomarker can establish complementary or alternative measurements of whole grain intake and is expected to overcome some of these obstacles (Ocke and Kaaks, 1997; Ross et al., 2004a). Alkylresorcinols (ARs) have been proposed to be biomarkers of whole grain wheat and rye intake (Ross et al., 2004b; Linko and Adlercreutz, 2005).

Alkylresorcinols are amphiphilic 1,3-dihydroxybenzene derivatives with an odd-numbered alkyl chain at position 5 (Fig. 1). The alkyl chain in cereal ARs varies from 15 to 27 carbon atoms. They are located in the intermediate layers between pericarp and testa in the grain (Landberg et al., 2008), and are found in high concentrations only in whole grain and/or bran products of wheat $(31.7-143.9 \mathrm{mg} / 100 \mathrm{~g}$ dry matter, DM) and rye (36.0-320.0 mg/100g DM), and in very small amounts in refined flour (white bread, most breakfast cereals, pasta) or in any other commonly consumed foods (Ross et al., 2003; Ross et al., 2004a; Ross and Kochhar, 2009; Annica et al., 2010). They are also present in triticale (43.9-64.7 $\mathrm{mg} / 100 \mathrm{~g} \mathrm{DM})$, and in small amounts in barley $(4.2-5.1 \mathrm{mg} / 100 \mathrm{~g} \mathrm{DM})$, but not in oats (Ross et al., 2003).<smiles>[R]c1cc(O)cc(O)c1</smiles>

Fig. 1. Structures of alkylresorcinols commonly found in cereal grains.

\begin{tabular}{c|c|c|c}
\hline $\mathrm{R}$ & ARs names & Short names & $\begin{array}{c}\text { Molecular } \\
\text { weight }\end{array}$ \\
\hline $\mathrm{C}_{15} \mathrm{H}_{31}$ & 5-n-pentadecylresorcinol & $\mathrm{C} 15: 0$ & 320 \\
$\mathrm{C}_{17} \mathrm{H}_{35}$ & 5-n-heptadecylresorcinol & $\mathrm{C} 17: 0$ & 348 \\
$\mathrm{C}_{19} \mathrm{H}_{39}$ & 5-n-nonadecylresorcinol & $\mathrm{C} 19: 0$ & 376 \\
$\mathrm{C}_{21} \mathrm{H}_{43}$ & 5-n-heneicosylresorcinol & $\mathrm{C} 21: 0$ & 404 \\
$\mathrm{C}_{23} \mathrm{H}_{47}$ & 5-n-tricosylresorcinol & $\mathrm{C} 23: 0$ & 432 \\
$\mathrm{C}_{25} \mathrm{H}_{51}$ & 5-n-pentacosylresorcinol & $\mathrm{C} 25: 0$ & 460
\end{tabular}


In vitro, ARs have been reported to have anticancer, enzyme-inhibiting, and DNA-cleaving properties (Kozubek and Tyman, 1999). ARs are reported to be antioxidants (Winata and Lorenz, 1996), although they are weak antioxidants in vitro compared with $\alpha$-tocopherol (Kamal-Aldin $e t$ al., 2001; Ross et al., 2004b; Korycińska et al., 2009). Another in vitro study (Ross et al., 2004c) showed that ARs significantly inhibited the conversion of $\gamma$-tocopherol to its water-soluble hydroxychroman metabolite, indicating that ARs may increase $\gamma$-tocopherol's levels via inhibition of tocopherol metabolism in vivo. A recent in vitro study (Stasiuk et al., 2008) showed that ARs isolated from rye grain decreased the enzymatic activity of acetylcholinesterase of erythrocytes. These findings are of interest due to the growing evidence that acetylcholinesterase could participate in the pathological processes of Alzheimer's disease. The biological activities of dietary and purified ARs have been previously reviewed (Kamal-Aldin et al., 2001; Ross et al., 2004b).

Different chromatographic methods for analysis of ARs in whole grain and cereal products have been developed over years. Gas chromatography - mass spectrometry (GC-MS) and high performance liquid chromatography (HPLC) are commonly used for the routine quantitative determination of ARs (Ross et al., 2001; Mattila et al., 2005; Landberg et al., 2006). For the rapid determination of total ARs content in cereal grain products, colorimetric method after formation of intense red complex with fast blue salt (the diazonium salt Fast Blue B) has been used (Mattila et al., 2005; Kulawinek and Kozubek, 2008). Fast Blue B has been used for quantitative determination of ARs in cereal grain extracts, but without reported validations of the methods used (Andersson et al., 2008). Recently, the HPLC method for the analysis of intact ARs in cereals using coularray detection (HPLC-CA) has been suggested. Use of the CA detector allowed detection of low concentrations of ARs in white wheat flour, which had not been reliably detected using previous methods (Ross and Kochhar, 2009).

In this paper we present a rapid and sensitive HPLC method for the analysis of ARs in whole grain cereals with ultra violet (UV) detector. This new method was developed based on method by Ross et al. (2001). HPLC-UV method is rather simple and does not require derivatization or any other sample pretreatment. However, validation parameters should be performed in next research.

\section{MATERIALS AND METHODS}

Chemicals and standards. The Alkylresorcinol standard C17:0 used had $\geq 95 \%$ purity as determined by the company from where it was purchased (Sigma-Aldrich, St.Luis, USA). Homologues C19:0 and C21:0 were of $>98 \%$ purity as determined by the company from where they were purchased (Reseachem Life Science, Burgdorf, Switzerland). All standards were prepared as stock solutions at $2.5 \mathrm{mg} / \mathrm{ml}$ in methanol/ethanol mixture and were stored in a freezer at $-18{ }^{\circ} \mathrm{C}$. All solvents were of HPLC-grade (Sigma-Aldrich, St.Luis, USA) and were used without further purification.
Cereal samples. Rye samples $(n=2)$ and triticale samples $(n=2)$ were provided by the State Priekuli Plant Breeding Institute (Priekuḷ, Latvia), and grains were harvested in 2010. Common spring wheat samples $(n=2)$ and barley samples $(n=2)$ were provided by the State Stende Cereals Breeding Institute (Stende, Latvia), and grain were harvested in 2010. Common winter wheat samples $(n=2)$, triticale samples $(n=1)$, rye samples $(n=4)$ and oat samples $(n=2)$ were also provided by the State Stende Cereals Breeding Institute (Stende, Latvia), and grains were harvested in 2011.

Extraction of samples. According to a slightly modified method of Ross et al. (2001), alkylresorcinols were extracted from $1.00 \mathrm{~g}$ cereal grains (coarsely ground in a coffee grinder, then milled with a mortar and pestle) with 40 $\mathrm{ml}$ of ethyl acetate for $24 \mathrm{~h}$ with continuous shaking at room temperature. The extracts were centrifuged at 4400 rpm for $10 \mathrm{~min}$ and the supernatants $(4 \mathrm{ml})$ were then evaporated to dryness in a rotary evaporator (Heidolph Laborata 4001 Efficient System, USA). Methanol (1 ml) was added and samples were filtered through $0.45 \mu \mathrm{m}$ filters before injection into the HPLC. All samples were extracted in duplicates, and the results are reported on a basis of fresh weight (FW). Alkylresorcinol homologues C17:0-C21:0 were quantified using an external standard method. Calibration curves were prepared with the following concentrations: 0 , 5, 20, 50, 70 and $100 \mu \mathrm{g} / \mathrm{ml}$. Alkylresorcinol homologues C15:0, C23:0 and C25:0 were identified according to their spectra (Kulawinek and Kozubek, 2008) and determined semiquantitatively by method of internal standard, with C21:0 homologue as an internal standard $(10 \mu \mathrm{g} / \mathrm{ml})$. Relative response factors for $\mathrm{C} 15: 0, \mathrm{C} 23: 0$ and $\mathrm{C} 25: 0$ homologues were calculated by taking into account the amount of homologue (based on molecular weight) injected into chromatographic column versus homologue C21:0. All quantifications were based on peak area.

HPLC-UV analysis. Method development and analysis were carried out on a Shimadzu Prominence HPLC with a SPD-20A Diode Array Detector scanning between 260 and $295 \mathrm{~nm}$. Separation of alkylresorcinol homologues was done with a Symmetry C-18 $(4.6 \times 150 \mathrm{~mm}, 5 \mu \mathrm{m})$ column from Waters. The gradient programme was used at a flow rate $1.00 \mathrm{ml} / \mathrm{min}$ starting with a mobile phase of methanol/water $(80 / 20)$ for $5 \mathrm{~min}$, followed by methanol/water (99.2/0.8) for $25 \mathrm{~min}$. The temperature of the column oven was set on $30{ }^{\circ} \mathrm{C}$ and $40 \mu \mathrm{l}$ of each sample were injected into the chromatographic column. Instrument detection limits (IDL) were determined for C17:0 homologue (0.48 $\mu \mathrm{g} / \mathrm{ml})$, for C19:0 homologue $(0.44 \mu \mathrm{g} / \mathrm{ml})$ and for C19:0 homologue $(0.47 \mu \mathrm{g} / \mathrm{ml})$, with a coefficient of variation < $3 \%$. IDL was determined to be signal (peak area) that is greater than the system noise. Within a specified probability, IDL was calculated according to the formula (Wells et al., 2011):

$\mathrm{X}_{\mathrm{IDL}}=\mathrm{t}_{\alpha, \mathrm{n}} \cdot$ relative standard deviation $\cdot$ amount standard / $100 \%$, where

$\mathrm{t}(\alpha=0.05 ; \mathrm{n}=8)=2.3646$ (Student T-table $).$ 


\section{RESULTS}

In the present study, a developed HPLC-UV method for quantitative determination of ARs in the cereals is described. A good homologue separation (an appropriate gradient), IDL lower then $0.5 \mathrm{mg} / 100 \mathrm{~g}$ and a relatively short time of total analysis, showed that this method is sensitive and rapid (Fig. 2).

The UV spectrum of the homologues in methanol is shown on Fig. 3. All the homologues showed characteristic spectra with maximum absorbance at $\lambda=275 \mathrm{~nm}$ and $\lambda=280 \mathrm{~nm}$.

Quantification of C15:0, C23:0 and C25:0 alkylresorcinol homologues was problematic due to the lack of these standards. We attempted to overcome this by using C21:0 as an internal standard. All data were converted to fresh weight $(\mathrm{FW})$, considering that the moisture content of cereals is about 14\% (Anonymous, 1992). Alkylresorcinols were found in rye, wheat, triticale, and barley, but not in oats (Table 1).

\section{DISCUSSION}

Results of the analysis of rye grains showed that ARs levels varied from 87.1 to $112 \mathrm{mg} / 100 \mathrm{~g} \mathrm{FW}$. These values are comparable to literature: $61.9-65.5 \mathrm{mg} / 100 \mathrm{~g}$ FW by Ross et al. (2003), $92.7 \mathrm{mg} / 100 \mathrm{~g} \mathrm{FW}$ by Mattila et al. (2005), $134.2 \mathrm{mg} / 100 \mathrm{~g} \mathrm{FW}$ by Landberg et al. (2009).

Average ARs concentration in the wheat samples analysed in this study was $34.8 \mathrm{mg} / 100 \mathrm{~g} \mathrm{FW}$. This value is comparable to the previously reported data: $28.8-425 \mathrm{mg} / 100 \mathrm{~g} \mathrm{FW}$ by Chen et al. (2004), 42.0-42.1 mg/100 g FW by Landberg et al. (2009). However, our results for wheat samples are
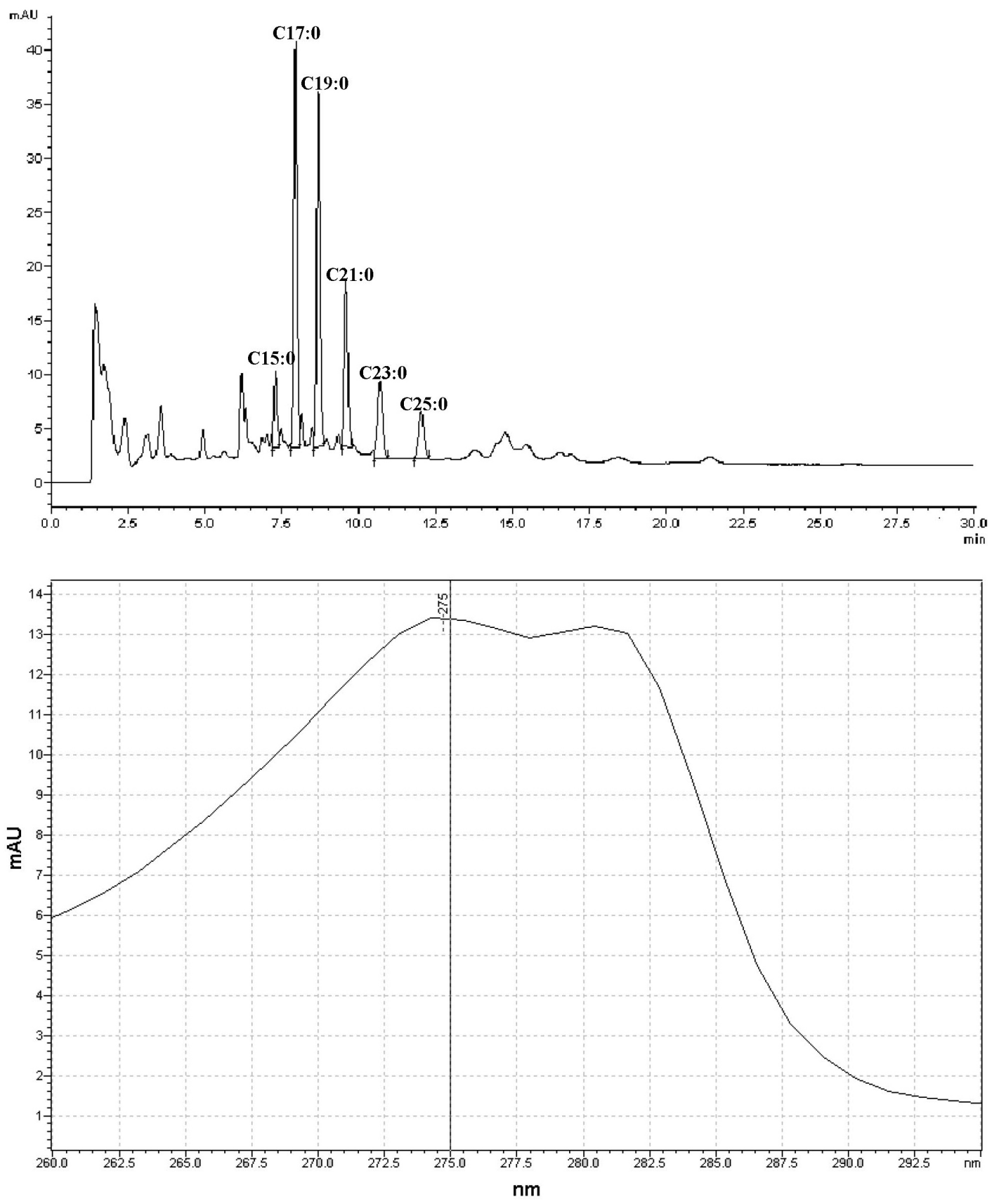

Fig. 2. HPLC-UV chromatogram of alkylresorcinol homologues in rye (Amilo) after extraction with ethyl acetate for $24 \mathrm{~h}$ at room temperature, centrifuged, evaporated and redissolved in methanol $(1 \mathrm{ml})$. See text for HPLC conditions.

Fig. 3. The characteristic spectrum of alkylresorcinol homologues in methanol. 
CONTENT OF ALKYLRESORCINOLS IN CEREAL GRAINS (mg/100 $\mathrm{g}$ of fresh weight) ${ }^{1}$

\begin{tabular}{|c|c|c|c|c|c|c|c|c|}
\hline Cereal & Cultivar & $\mathrm{C} 15: 0$ & C17:0 & C19:0 & C21:0 & $\mathrm{C} 23: 0$ & $\mathrm{C} 25: 0$ & Total ARs \\
\hline \multirow[t]{6}{*}{ Rye } & 04014-4 & $0.8 \pm 0.4^{2}$ & $24 \pm 4$ & $28 \pm 2$ & $21.8 \pm 0.3$ & $21 \pm 2^{2}$ & $12 \pm 1^{2}$ & 107.6 \\
\hline & Amilo & $2.18 \pm 0.05$ & $30.5 \pm 0.7$ & $26.8 \pm 0.5$ & $14.3 \pm 0.5$ & $9.6 \pm 0.7$ & $4.6 \pm 0.5$ & 88.0 \\
\hline & Kaupo & $1.14 \pm 0.07$ & $31.8 \pm 0.1$ & $29.5 \pm 0.1$ & $19.7 \pm 0.2$ & $14.6 \pm 0.7$ & $8.9 \pm 0.1$ & 105.6 \\
\hline & Dankovskie Diament & $2.8 \pm 0.3$ & $34 \pm 2$ & $30 \pm 2$ & $19 \pm 1$ & $14.5 \pm 0.3$ & $8.8 \pm 0.6$ & 109.1 \\
\hline & 9918 & $1.75 \pm 0.02$ & $25 \pm 2$ & $25 \pm 1$ & $16.3 \pm 0.8$ & $10.9 \pm 0.9$ & $8.1 \pm 0.4$ & 87.1 \\
\hline & Picaso & $2.0 \pm 0.4$ & $34 \pm 4$ & $31 \pm 2$ & $22 \pm 2$ & $14 \pm 2$ & $9 \pm 1$ & 112.0 \\
\hline \multirow{2}{*}{$\begin{array}{l}\text { Common spring } \\
\text { wheat }\end{array}$} & L920 Uffo & $\mathrm{nd}^{3}$ & $1.96 \pm 0.05$ & $13.7 \pm 0.2$ & $20.2 \pm 0.6$ & $4 \pm 1$ & $0.38 \pm 0.03$ & 40.2 \\
\hline & L934 Eminent & nd & nd & $5 \pm 1$ & $11 \pm 2$ & $7.7 \pm 0.2$ & $0.343 \pm 0.004$ & 24.0 \\
\hline \multirow{2}{*}{$\begin{array}{l}\text { Common winter } \\
\text { wheat }\end{array}$} & Spelta (ID) & nd & $3.9 \pm 0.1$ & $8.3 \pm 0.6$ & $18.3 \pm 0.4$ & $5.8 \pm 0.2$ & $0.97 \pm 0.09$ & 37.3 \\
\hline & $96-58$ & nd & $5 \pm 1$ & $13.6 \pm 0.2$ & $16.7 \pm 0.1$ & $2.1 \pm 0.1$ & $0.34 \pm 0.02$ & 37.7 \\
\hline \multirow[t]{3}{*}{ Triticale } & Falmoro & nd & nd & $3.2 \pm 0.3$ & $9.5 \pm 0.7$ & $16 \pm 3$ & $3.4 \pm 0.2$ & 32.1 \\
\hline & Nazaret & nd & $4 \pm 2$ & $12 \pm 4$ & $15 \pm 2$ & $11.1 \pm 0.4$ & $2.0 \pm 0.2$ & 44.1 \\
\hline & $9402-3$ & nd & $12.1 \pm 0.7$ & $23 \pm 1$ & $21.0 \pm 0.7$ & $15 \pm 2$ & $3.28 \pm 0.01$ & 74.4 \\
\hline \multirow[t]{2}{*}{ Barley } & Jet & nd & nd & nd & $1.5 \pm 2$ & $0.17 \pm 0.02$ & $2.0 \pm 0.8$ & 3.7 \\
\hline & 1196 & nd & nd & nd & $1.2 \pm 0.8$ & nd & $1.0 \pm 0.7$ & 2.2 \\
\hline \multirow[t]{2}{*}{ Oats } & S-156 & nd & nd & nd & nd & nd & nd & nd \\
\hline & Arta & nd & nd & nd & nd & nd & nd & nd \\
\hline \multicolumn{9}{|c|}{$\overline{{ }^{1} \text { Values are average } \pm \text { standard deviation }}$} \\
\hline \multicolumn{9}{|c|}{${ }^{2}$ C15:0, C23:0 and C25:0 - semiquantitative results. } \\
\hline - mot detes & & & & & & & & \\
\hline
\end{tabular}

lower than those obtained by Ross et al. (2003) - ARs levels in common wheat grains varied from 42 to 122.9 $\mathrm{mg} / 100 \mathrm{~g} \mathrm{FW}$, by Mattila et al. (2005) — whole wheat flour contained $75.9 \mathrm{mg} / 100 \mathrm{~g} \mathrm{FW}$ of ARs and, also by Kulawinek and Kozubek (2008) ground wheat grains contained $57.8 \mathrm{mg} / 100 \mathrm{~g} \mathrm{FW}$ of ARs (for C15:0-C 19:0 homologues). This variation is probably due in part to differences in analytical methods and also the ARs content of cereals appears to be highly variable, depending on cultivar and environmental conditions.

Alkylresorcinol concentration in triticale varied from 32.1 to $74.4 \mathrm{mg} / 100 \mathrm{~g} \mathrm{FW}$, and is comparable to those reported previously (37.8-55.6 mg/ 100g FW) by Ross et al. (2003). Unfortunately, this cereal is not commonly consumed by humans.

The total ARs concentration in barley varied from 2.2. to $3.7 \mathrm{mg} / 100 \mathrm{~g}$ FW. These values are in line with those reported by Ross et al. (2003 — from 3.6 to $4.4 \mathrm{mg} / 100 \mathrm{~g}$ FW, by Mattila et al. (2005) - $3.2 \mathrm{mg} / 100 \mathrm{~g} \mathrm{FW}$, although lower than reported by Landberg et al. (2009) - 7.7 $\mathrm{mg} / 100 \mathrm{~g} \mathrm{FW}$. The difference is probably because of use of different extraction solvents and, of course, different environmental conditions. Also, a cereal specific correction factor was used by Landberg et al. (2009). The factor was calculated by taking into account differences in molecular weight and the average relative homologue composition (determined by GC) of the particular cereal. None was found in oats.

According to our results, the main ARs homologues in rye are C17: 0 and C19:0; in wheat are C19:0 and C21:0; in triticale are $\mathrm{C} 21: 0$ and $\mathrm{C} 23: 0$; in barley are $\mathrm{C} 21: 0$ and
C25:0. In addition, the mean total content of ARs in analyzed grain samples was in the following sequence: rye $>$ triticale $>$ wheat $>$ barley $>$ oats. Nonetheless, more data need to be collected about ARs concentration in different cereals breed in Latvia.

This HPLC-UV method is appropriate for ARs determination in cereals, due to its simplicity, rapidity and sensitiveness.

\section{ACKNOWLEDGEMENTS}

The study was financed by the State Stende Cereals Breeding Institute (Stende, Latvia), project framework of the European Regional Development Fund (ERAF) „Assessment of Local Origin Cereal Species' Potential and Development of Varieties for Specific Dietary Foods Production" (No. 2010/0273/2DP/2.1.1.0/10/APIA/VIAA/083). Grain samples were provided by the State Priekulti Plant Breeding Institute (Priekuli, Latvia) and by the State Stende Cereals Breeding Institute (Stende, Latvia). The authors wish to thank Māris Jākobsons and Oksana Rotkaja for their skilled technical assistance.

\section{REFERENCES}

Andersson, M. A. A, Kamal-Eldin, A., Fras, A., Boros, D., Åman, P. (2008). Alkylresorcinols in wheat varieties in the HEALTHGRAIN Diversity Screen. J. Agric. Food Chem., 56 (21), 9722-9725.

Andersson, M. A. A, Åman, P., Wandel, M., Frølich, W. (2010). Alkylresorcinols in wheat and rye flour and bread. J. Food Compos. Anal., 23 (8), 794-801.

Anonymous (1992). Food and Agriculture Organization. European Community Intervention Regulations on Minimum Quality Standards (1992, 
March), Commission Regulation (EEC) No 689/92. http://www.fao.org/docrep/T1838E/T1838E0O.GIF

Bingham, A. S., Luben, R., Welch, A., Wareham, N., Khaw, T.-K., Day, N. (2003). Are imprecise methods obscuring a relation between fat and breast cancer? Lancet, 362 (9379), 212-214.

Chen, Y., Ross, B. A., Åman, P., Kamal-Eldin, A. (2004). Alkylresorcinols as markers of whole grain wheat and rye in cereal products. J. Agric. Food Chem., 52 (26), 8242-8246.

Fung, T. T., Rimm, B. E, Spiegelman, D., Rifai, N., Tofler, H. G., Willett, C. W., Hu, B. F. (2001). Association between dietary patterns and plasma biomarkers of obesity and cardiovascular disease risk. Amer. J. Clin. Nutr., 73, 61-67.

Jacobs, D. R. Jr., Marquart, L., Slavin, J., Kushi, L. H. (1998). Whole-grain intake and cancer: An expanded review and meta-analysis. Nutr. Cancer, 30 (2), 85-96.

Kaaks, J. R. (1997). Biochemical markers as additional measurements in studies of the accuracy of dietary questionnaire measurements: Conceptual issues. Amer. J. Clin. Nutr., 65 (4), 1232S-1239S.

Kamal-Eldin, A., Pouru, A., Eliasson, C., Åman, P. (2001). Alkylresorcinols as antioxidants: Hydrogen donation and peroxyl radical-scavenging effects. J. Sci. Food Agric., 81 (3), 353-356.

Korycińska, M., Czelna, K, Jaromin, A., Kozubek A (2009). Antioxidant activity of rye bran alkylresorcinols and the extracts from whole-grain cereal products. Food Chem., 116 (4), 1013-1018.

Kozubek, A., Tyman, J. H. (1999). Resorcinolic lipids, the natural nonisoprenoid phenolic amphiphiles and their biological activity. Chem. Rev., 99 (1), 1-26.

Kulawinek, M., Kozubek, A. (2008). Quantitative determination of alkylresorcinols in cereal grains: Independence of the length of the aliphatic side chain. J. Food Lipids, 15, 251-262.

Landberg, R., Kamal-Eldin, A., Salmenkallino-Marttila, M., Åman, P. (2008). Localization or alkylresorcinols in wheat, rye and barley kernels. $J$. Cereal Sci., 48 (2), 401-406.

Landberg, R., Kamal-Eldin, A., Andersson, R., Åman, P. (2006). Alkylresorcinol content and homologue composition in durum wheat (Triticum durum) kernels and pasta products. J. Agric. Food Chem., 54 (8), 3012-3014.

Landberg, R., Andersson M. A. A., Åman, P., Kamal-Eldin, A. (2009). Comparison of GC and colorimetry for the determination of alkylresorcinol homologues in cereal grains and products. Food Chem., 113 (4), $1363-1369$.

Lang, R., Jebb, A. S. (2003). Who consumes whole grains, and how much? Proc. Nutr. Soc., 62, 123-127.
Linko, A.- M., Adlercreutz, H. (2005). Whole grain rye and wheat alkylresorcinols are incorporated into human erythrocyte membranes. Brit. J. Nutr., 93 (1), 11-13.

Liu, S., Stampfer, J. M., Hu, B. F., Giovannucci, E., Rimm, E., Manson, E. J., Hennekens, H. C., Willet, C. W. (1999). Whole-grain consumption and risk of coronary heart disease: Results from the Nurses' Health Study. Amer. J. Clin. Nutr., 70 (3), 412-419.

Mattila, P., Pihlava, M. J., Hellström, J. (2005). Contents of phenolic acids, alkyl- and alkenylresorcinols, and aventramides in commercial grain products. J. Agric. Food Chem., 53 (21), 8290-8295.

Munter, S. J., Hu, B. F., Spiegelman, D., Franz, M., Dam van, M. R. (2007). Whole grain, bran, and germ intake and risk of type 2 diabetes: A prospective cohort study and systematic review. PLoS Med., 4 (8), e261.

Ocke, C. M., Kaaks, J. R. (1997). Biochemical markers as additional measurements in dietary validity studies: Application of the method of triads with examples from the European Prospective Investigation into Cancer and Nutrition. Amer. J. Clin. Nutr., 65 (4), 1240S-1245S.

Ross, B. A., Åman, P., Kamal-Eldin, A. (2004a). Identification of cereal alkylresorcinol matabolites in human urine - potential biomarkers of whole grain wheat and rye intake. J. Chromatogr., B 809 (1), 125-130.

Ross, B. A., Kamal-Eldin A., Åman, P. (2004b). Dietary alkylresorcinols: Absorption, bioactiviteis, and possible use as biomarkerz of whole-grain wheat- and rye- rich foods. Nutr. Rev., 62 (3), 81-95.

Ross, B. A., Kochhar, S. (2009). Rapid and sensitive analysis of alkylresorcinols from cereal grains and products using HPLC Coularray-Based Electrochemical Detection. J. Agric. Food Chem., 57 (12), 5187-5193.

Ross, B. A., Shepherd, J. M., Schüpphaus, M., Sinclair, V., Alfaro, B., Kamal-Eldin, A., Åman, P. (2003). Alkylresorcinols in cereals and cereal products. J. Agric. Food Chem., 51 (14), 4111-4118.

Ross, A. B., Chen, Y., Frank, J., Swanson, J. E., Parker, R. S., Kozubek, A., Lundh, T., Vessby, B., Åman, P., Kamal-Eldin, A. (2004c). Cereal alkylresorcinols elevate gamma-tocopherol levels in rats and inhibit gammatocopherol metabolism in vitro. J. Nutr., 134 (3), 506-510.

Ross, B. A., Kamal-Eldin, A., Jung, C., Shepherd, J. M., Åman, P. (2001). Gas chromatographic analysis of alkylresorcinols in rye (Secale cereale $\mathrm{L}$ ) grains. J. Sci. Food Agric., 81 (14), 1405-1411.

Slavin J. (2003). Why whole grains are protective: Biological mechanisms. Proc. Nutr. Soc., 62 (1), 129-134.

Stasiuk, M., Bartosiewicz, D., Kozubek, A. (2008). Inhibitory effect of some natural and semisynthetic phenolic lipids upon acetylcholinesterase activity. Food Chem., 108 (3), 996-1001.

Wells, G., Prest, H., Russ, C. W. (2011). Why use signal-to-noise as a measure of MS performance when it is often meaningless? Spectroscopy, 26 (5), S28-S34.

Winata, A., Lorenz, K. (1996). Antioxidant potential of 5- $n$-pentadecylresorcinol. J. Food Process. Preserv., 20 (5), 417-429.

Received 12 April 2013

\section{ALKILREZORCĪNU SATURA NOTEIKŠANA LATVIJĀ AUDZĒTOS GRAUDOS AR AUGSTI EFEKTĪVU ŠĶIDRUMU HROMATOGRĀFIJU AR ULTRAVIOLETU DETEKTORU}

Graudaugu alkilrezorcīni (AR) ir savienojumu grupa, kur viena molekulas daḷa ir fenola atlikums, bet otra ir lipīdu atlikums. AR lielā daudzumā atrodas grauda ārējos slān,os (graudapvalkos, aleirona slānī) galvenokārt rudzu un kviešu graudos, kā arī nelielos daudzumos miežos. Rafinētos produktos AR ir niecīgos daudzumos vai vispār nav. Tieši tāpēc AR tiek piedāvāts lietot par selektīvu pārtikas biomarķieri, lai patēēēājiem būtu vieglāk saprast, kurš produkts ir pilngraudu vai satur pilngraudus. Pilngraudu produktu patērēšana ir saistīta ar samazinātu risku saslimt ar dažādām hroniskām slimībām: aptaukošanās, 2. tipa diabēts, sirds slimības un vēzis. Šajā publikācijā tiek prezentēta ātra un jutīga augsti efektīvu škidrumu hromatogrāfija ar ultravioletu detektoru - metode alkilrezorcīnu noteikšanai Latvijā audzētos graudaugos. Instrumenta detektēšanas robeža tika noteikta C17:0, C19:0 un C21:0 homologiem (variācijas koeficients < 3\%). AR saturs rudzos bija robežās no 87,1 līdz 112,0 mg/100g, kviešos no 24,0 līdz 40,2 mg/100g, tritikālē no 32,1 līdz 74,4 mg/100g, nedaudz miežos no 2,2 līdz $3,7 \mathrm{mg} / 100 \mathrm{~g}$, bet auzās netika atrasts. 